OPEN ACCESS

Edited by:

Joel Guiot,

Centre National de la Recherche Scientifique, France

Reviewed by:

Séverine Fauquette,

Centre National de la Recherche

Scientifique, France

Manuel Hernández Fernández, Complutense University of Madrid,

Spain

*Correspondence: Tamara Fletcher

Tamara.Fletcher@umontana.edu

Specialty section: This article was submitted to

Paleoecology,

a section of the journal

Frontiers in Ecology and Evolution

Received: 18 January 2017

Accepted: 13 March 2017

Published: 31 March 2017

Citation:

Fletcher T, Feng R, Telka AM, Matthews JV Jr. and Ballantyne A (2017) Floral Dissimilarity and the Influence of Climate in the Pliocene

High Arctic: Biotic and Abiotic

Influences on Five Sites on the Canadian Arctic Archipelago.

Front. Ecol. Evol. 5:19.

doi: 10.3389/fevo.2017.00019

\section{Floral Dissimilarity and the Influence of Climate in the Pliocene High Arctic: Biotic and Abiotic Influences on Five Sites on the Canadian Arctic Archipelago}

\author{
Tamara Fletcher ${ }^{1 *}$, Ran Feng ${ }^{2}$, Alice M. Telka ${ }^{3}$, John V. Matthews Jr. ${ }^{4}$ and \\ Ashley Ballantyne ${ }^{1}$
}

1 Global Climate \& Ecology Laboratory, Department of Ecosystem and Conservation Sciences, University of Montana, Missoula, MT, USA, ${ }^{2}$ Climate and Global Dynamics Laboratory, University Corporation for Atmospheric Research, Boulder, CO, USA, ${ }^{3}$ Paleotec Services, Ottawa, ON, Canada, ${ }^{4}$ The Shopudio, Hubley, NS, Canada

A recurring goal in ecological and paleoclimatic studies is to either forecast how ecosystems will respond to future climate or hindcast climate from past ecosystem assemblages. The Pliocene is a useful deep-time laboratory for understanding an equilibrium climate state under modern atmospheric $\mathrm{CO}_{2}$, and has been a focus for climate modelers. Accurate estimates of proxy data-model mismatch are hindered by the scarcity of well-constrained observations from well-dated sites in the High Arctic. Using a recently developed community-based approach (Climate Reconstruction Analysis using Coexistence Likelihood Estimation: CRACLE) compared with an established method (The Coexistence Approach: CA), and applied to extraordinary, permafrost-driven preservation of floras, we explore the climate and community assemblages at five Pliocene sites in the Canadian Arctic Archipelago. The results suggest that climatic differences at this scale do not simply correlate to differences in community assemblage between sites. The threshold temperature for tree line is one important component, but other factors in the environment (e.g., soil characteristics) may drive dissimilarity of communities where the taxa could share the same climate space. Estimates from CRACLE agree with previous estimates where available, and generally fall within the ranges of CA. Mean annual temperatures were $\sim 22^{\circ} \mathrm{C}$ hotter (ranging from 0.8 to $6.2^{\circ} \mathrm{C}$ by species across sites) and mean annual precipitation $\sim 500 \mathrm{~mm}$ wetter (ranging from 530 to $860 \mathrm{~mm}$ by species across sites) during the Early to "mid"-Pliocene ( $3.6 \mathrm{Ma}$ ) when compared with modern climate station data in the Canadian Arctic Archipelago. Comparison of estimates for three levels of taxonomic input suggest judicious interpretation is needed when generic level identifications are used, especially in the Polar Regions. The results herein are a reminder of the large impact of non-climatic abiotic and biotic factors to be accounted for when predicting future ranges of communities under different climate conditions from the present, and when hindcasting climate from past ecosystem assemblages.

Keywords: biogeography, CRACLE, Raup-Crick, community assembly, climate-vegetation interactionsm, Pliocene, Canadian Arctic Archipelago, plant macrofossils 


\section{INTRODUCTION}

The mid-Pliocene, $\sim 3.6 \mathrm{Ma}$, represents an equilibrium climate state under a radiative forcing similar to present-day (Jansen et al., 2007) and is often considered our nearest historical analog for future climate. In common with the modern system, atmospheric carbon dioxide concentrations during the midPliocene have been estimated at $\sim 400 \mathrm{ppm}$ (Pagani et al., 2010; Haywood et al., 2016; Stap et al., 2016). Additionally, the broad physical characteristics of the Earth, such as approximate continental configurations, are also comparable to modern (Haywood et al., 2016). Unlike the modern climate, temperatures were $3-4^{\circ} \mathrm{C}$ warmer globally than present (Haywood et al., 2010; Fedorov et al., 2013) and proxy estimates suggest mean annual temperatures were $14-22^{\circ} \mathrm{C}$ warmer in the Western Arctic (Elias and Matthews, 2002; Ballantyne et al., 2006, 2010; Csank et al., 2011a,b) and $\sim 8^{\circ} \mathrm{C}$ warmer during the warmest month in northern Eurasia (BrighamGrette et al., 2013), a phenomenon referred to as polar amplification. Although these estimates have provided key information about the Arctic environment, they are spatially sparse and generally lack information about the hydrological cycle of the Arctic region (c.f. Brigham-Grette et al., 2013). Very little is known about changes in precipitation for the Western Arctic when Pliocene temperatures were clearly much warmer.

The scarcity of well-constrained proxy estimates and observations from well-dated sites in the terrestrial Arctic limits the accuracy of boundary conditions for vegetation set in the climate models and evaluation of the model performances by direct comparison (Haywood et al., 2013; Salzmann et al., 2013). Although not a direct analog, improving reconstructions of the Pliocene Arctic climate and environment would also help explore the effect of abiotic and biotic changes in the Arctic in the context of the global climate change (Melles et al., 2012). The radically different Arctic climates of the past and the amplification of Arctic temperature warming today (McBean et al., 2005) make the Arctic system a key component for understanding future climate change. At the same time, we would like to move beyond our understanding of how single species respond to climate change and try to understand how climate affects the community assemblage in response to climate. This study attends to these needs by providing quantitative climate estimates and floral community assemblage information, for five Early to mid-Pliocene High Arctic terrestrial fossil localities.

It was anticipated that climate was the primary control on the distribution of plant taxa across the Canadian Arctic Archipelago (CAA) during the Early to mid-Pliocene, and thus sites that are more different in terms of the climate estimates will differ more in terms of community composition. This may also be expected because the climate estimates are being calculated from the communities, however, if other environmental factors are a stronger control on community assembly, taxa found in the same climatic range may be partitioned.

\section{MATERIALS AND METHODS}

\section{Localities}

The fossil communities used in this study (Figure 1) come from the Pliocene Beaufort Formation and Beaufort ageequivalent "High Terrace Sediments" of the CAA, which comprise unlithified sand and gravel containing organic deposits from braided rivers (Fyles, 1990). These rivers were likely surrounded by forests that may have extended all the way to the Arctic Ocean during parts of the Pliocene, nearly eliminating the tundra biome (Salzmann et al., 2008). Found within the organic deposits are remarkably preserved woody debris from the forests (Devaney, 1991; Fyles et al., 1994; Murphy, 2006; Murphy et al., 2007) up to half a meter thick (Davies et al., 2014), and layers of well-preserved leaf litter comprising leaves, twigs, mosses, pollen, charcoal, and invertebrate remains (Fyles, 1990; Matthews and Ovenden, 1990; Elias and Matthews, 2002; Tedford and Harington, 2003; Rybczynski et al., 2013; Fletcher et al., 2016). The deposits also preserve a fascinating mammalian fauna (Tedford and Harington, 2003; Rybczynski et al., 2013), some of which challenge previous hypotheses for the evolutionary and ecological history of modern lineages (Rybczynski et al., 2013). Thus, the study of the climate and environment of these fossil communities may also improve our understanding of the past ecology that shaped the evolution of modern mammalian forms.

\section{Dating Constraints and Uncertainties}

Dating of the Beaufort Formation and "High Terrace Sediments" is complicated by the combination of unconsolidated, often coarse sands, proximity to the pole, and absence of volcanic sediments in the formations. These sites have been dated using techniques including biostratigraphy of the flora (Matthews and Ovenden, 1990), and fauna (McNeil, 1990; Fyles et al., 1994; Tedford and Harington, 2003) the relative stratigraphic position (Fyles et al., 1994) and timing of eustatic highs (BrighamGrette and Carter, 1992), magnetostratigraphy (Fyles et al., 1991), Strontium (Sr) isotope analysis (Kaufman et al., 1990), amino acid racemization (Brigham-Grette et al., 1987; Fyles et al., 1991), and more recently absolute dates obtained from terrestrial cosmogenic nuclides (TCN; Rybczynski et al., 2013). Justification for our current interpretation of the ages of the sites in this study follows below, and is shown in Figure 2, however, the errors on these estimates are substantial and a more tightly constrained chronology of the sites would increase their value to Pliocene climate modelers and for understanding the geologic and evolutionary history of the CAA.

Both Fyles Leaf Beds (FLB) and Beaver Pond (BP) sites from the "High Terrace Sediments" in this study, have been absolutely dated using TCN (Rybczynski et al., 2013), yielding minimum ages of $3.8+1 /-0.7$ and $3.4+0.6 /-0.4$, respectively, and thus overlap within one standard error. The relative elevation between the significant peat layers at the two sites, both at $\sim 400 \mathrm{~m}$ elevation, supports an approximate coeval deposition. In addition, they share specific informative floral elements such as Paliuris and shared components of faunal assemblages (Rybczynski et al., 2013). 


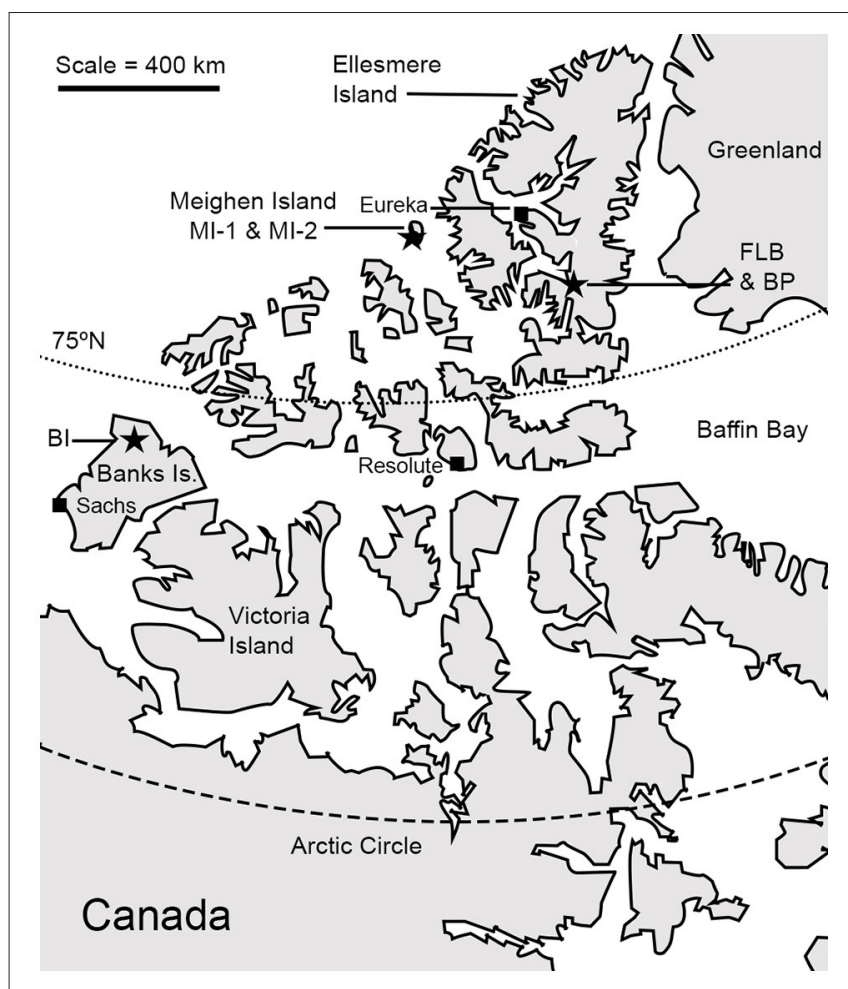

FIGURE 1 | A map of the Canadian High Arctic showing the modern locations of the fossil sites reported in this study (stars), modified from Davies et al. (2014). Banks Island flora (BI: 74.30, -123.50), Meighen Island Lower flora (Ml-1: 79.85, -99.24), Meighen Island Upper flora (Ml-2: 79.85, -99.24), Beaver Pond flora (BP: 78.55, -82.33), Fyles Leaf Bed flora (FLB: $78.50,-82.60)$.

The date for the Beaufort Formation at Meighen Island was previously considered to be $\sim 3 \mathrm{Ma}$ based on the estimated age of the marine incursion layer that separates the lower sediments of the Beaufort Formation on Meighen Island (MI-1) from the upper sediments of Meighen Island (MI-2), and this age is still often cited in the literature (e.g., Elias and Matthews, 2002; Haywood et al., 2016). This estimated age was primarily based on the discovery of a mixed molluscan fauna, comprising both Atlantic and Pacific Ocean species, suggesting a date of deposition proximal to the opening of the Bering Strait, secondarily evaluated using magnetostratigraphy (Fyles et al., 1991). It was compared to the then best known site with a similar mixed flora and magnetostratigraphic record-the Tjornes Beds, Iceland. The dates of the Tjornes Beds have been revised several times since (Fyles et al., 1991). The most recent, and perhaps complete dating of the section, places the mixed molluscan flora recognized at this site, at the base of the Serripes Zone at 4.4-4.5 Ma based on dinoflagellate cyst stratigraphy and paleomagnetic correlation with the top of the Nunivak subchron (Verhoeven et al., 2011).

The opening of the Bering Strait and ages of mixing of the Atlantic and Pacific molluscan faunas, has also been re-evaluated (Marincovich, 2000; Marincovich and Gladenkov, 2001; Gladenkov et al., 2002). Marincovich (2000) suggested

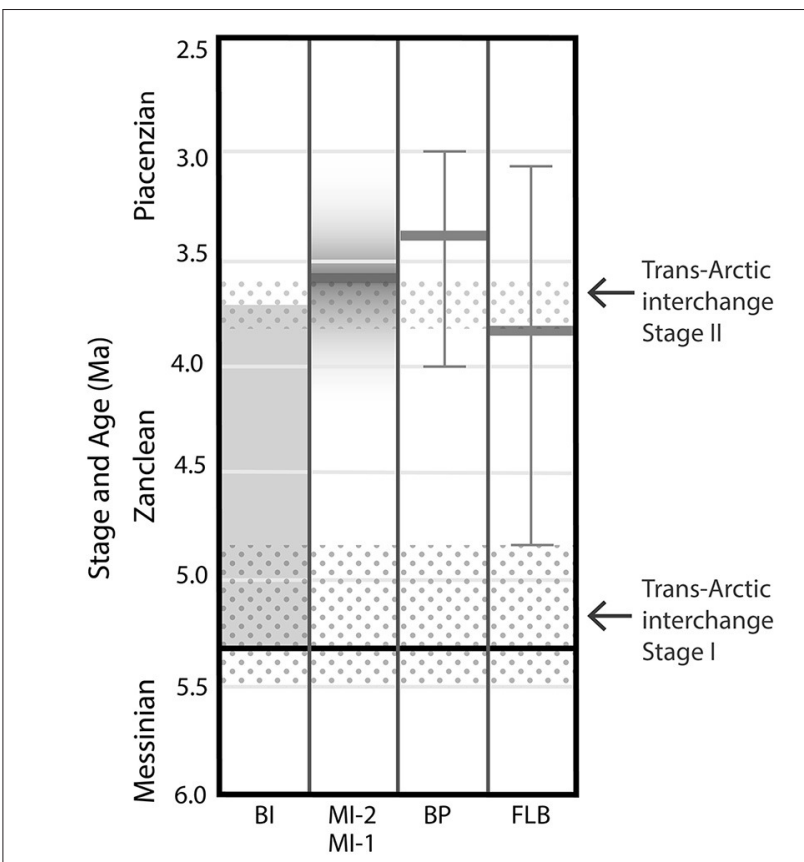

FIGURE 2 | Diagram showing relative age estimates of the five localities compared in this study. Shading represents ages based on relative stratigraphic or biostratigraphic methods. The age of the Meighen Island marine incursion layer between $\mathrm{Ml}-1$ and $\mathrm{Ml}-2$ is based on multiple methods outlined in the text. Dark line and tails represent absolute dates by Terrestrial Cosmogenic Nuclide dating. Floral and faunal composition also constrain the sites to the Pliocene, possibly Early Pliocene, not shown.

that there were multiple mixing events, with one following the first opening of the Bering Strait (4.8-5.5 Ma), and a second mixing event due to the change of direction of flow through the strait, arguably due to shoaling of the Central American Seaway ( 3.6 Ma; Although see Ramírez et al., 2016). These two periods also coincide with eustatic episodes (Marincovich, 2000). The thickness of the marine beds $(<100 \mathrm{~m})$ was considered to suggest a short period of deposition (Fyles et al., 1991), and this may be a "better fit" for the shorter high stand at $3.6 \mathrm{Ma}$. However, the sequence of opening, shoaling and complete closure of the key seaways is not agreed on in the literature, and the interchange of fauna may have persisted beyond initial mixing.

The ages of the Meighen Island marine incursion layer have also been subject to other dating attempts. Sr isotope dating of marine shell estimated an age range of 2.5-5.1 Ma (Kaufman et al., 1990), and, amino acid racemization indicated the ground temperature following deposition must have been freezing or below to promote the degree of amino acid preservation observed thus suggesting the shells were not subject to high temperatures, such as those of the Early Pliocene, for an extended time (Brigham-Grette et al., 1987; Brigham-Grette and Carter, 1992). The ages were also constrained for the marine incursion by biostratigraphic correlation of marine foraminifera to between 2.4 and 5.33 Ma (McNeil, 1990). Together, these lines of evidence are consistent with deposition of the marine incursion layer on Meighen Island at approximately the boundary between the 
Zanclean and Piacenzian. Thus we consider the MI-1 flora to be $\sim 3.6$ Ma or older, and MI-2 3.6 or younger.

The early reports of the Banks Island Beaufort Formation (BI) age was suggested relative to Meighen Island, while noting that some of the flora indicated an Early Pliocene age, and that the composition more generally suggested an age younger than Miocene (Fyles et al., 1994). Having reviewed the dating of the MI marine incursion we consider that this may also impact the likely age of the Beaufort Formation at BI. Thus, the BI Beaufort Formation age remains poorly known.

The oldest and youngest ages for all sites in the study are additionally constrained by key elements of the flora. For example, five-needle Pinus have been recorded in the Banks Island flora, both Meighen Island floras and the BP flora and is considered an indicator of pre-Quaternary environments in the High Arctic. The presence of the myriaceous taxa Myrica (Gale) and Comptonia also strongly suggests a Pliocene or older age, although their precise Last Appearance Datum (LAD) is not known. Epiprenum crassum's LAD in Europe is Early Pliocene (Matthews et al., 2003), thus the presence of this taxon at BI and MI-1 but not MI-2 despite significant sampling and investigation, while acknowledging that absence of evidence is not evidence of absence, may lend support to the Meighen Island marine incursion occurring at the Zanclean-Piacenzian boundary.

Faunal elements lend another line of evidence constraining the ages presented here. Tedford and Harington (2003) compared the vertebrate elements of BP to the Early Pliocene Yushe Basin faunas of northeastern China, and suggested an age of 4-5 Ma, as well as an active interchange across the Bering Strait. The insect fauna generally does not have biostratigraphic significance, but where some constraints are suggested, they confirm the Pliocene ages assigned to the localities (Elias and Matthews, 2002).

Based on these considerations, we suggest that the ages of these sites may fall at approximately the Zanclean-Piacenzian boundary, however, due to substantial uncertainties, only the two Meighen Island sites can be assigned a definite sequence relative to each other.

\section{Climate Methods}

We adopted the plant taxon lists for this study (Data Sheet S1), from Fyles et al. (1994), Matthews and Ovenden (1990), Matthews and Fyles (2000), and combined these with previously unpublished taxa lists. These identifications were derived from a wide range of remains of plant macrofossils preserved in sediments best described as peats through to leaf beds with little decomposition evident, protected by permafrost that has covered the area for much of the period since their deposition. Each locality herein may refer to one site or a group of sites in the same region that is suspected on stratigraphic evidence to be of a similar age, and is considered by Matthews to be one flora.

The identification of many of the elements of the floras to extant taxa provides the opportunity to apply both new methods and established methods to estimate the paleoclimate. The recently devised Climate Reconstruction Analysis using Coexistence Likelihood Estimation (CRACLE) derives the most likely climate for the combination of floral elements identified using joint likelihood functions, based on modern distribution data from the GBIF database (Harbert and Nixon, 2015). The CRACLE estimate median differs from the modern WorldClim dataset by an average of $<1.5^{\circ} \mathrm{C}$, significantly improving on the error from previous paleovegetation methods (Harbert and Nixon, 2015), while integrating more of the available community data thus mitigating the effect of mixed floras, and addressing some methodological concerns of the commonly implemented coexistence approach (CA; For detailed discussion see Grimm and Potts, 2016). The CRACLE estimates are compared to the CA (Full results see Data Sheet S2; Mosbrugger and Utescher, 1997), which calculates climate estimates based on the total overlap of climate tolerances of the nearest living relatives of the flora nonprobabilistically, but modified from the classical approach in that we did not use nearest living analogs for extinct species, we only used those that are extant (see Data Sheet S1).

For our climate reconstructions, three subsets of the data were derived from the plant taxa listed in Data Sheet S1, which capture a trade-off between increasing sample size and decreasing precision in identification (Table 1). The three subsets of data include: (1) confident identifications of extant taxa at the species level (referred to from this point as species), (2) confident identifications of extant taxa at the species level and taxa that compare well to extant taxa at the species level (referred to from this point as species cf.), and (3) those that are confidently assigned to the genus level with extant members (genera). The occurrence records for each list were accessed from the Global Biodiversity Information Facility (GBIF; Hijmans et al., 2005) via Darwin Core Archive. Those observations for which the value for "hasCoordinate" was false and/or "hasGeospatialIssues" was true, were removed. The remaining occurrence records were used for the input into the CRACLE code (Harbert and Nixon, 2015) for R (R Core Team, 2013), with some modifications to the body of the script guided by Harbert ( $\mathrm{R}$ library in development).

TABLE 1 | The number of taxa included in analyses, by level of identification and site.

\begin{tabular}{lll}
\hline Site & Level of analysis & Taxa used \\
\hline $\mathrm{Bl}$ & Species & 17 \\
& Species cf. & 28 \\
& Genera & 56 \\
\hline $\mathrm{Ml}-1$ & Species & 10 \\
& Species cf. & 12 \\
& Genera & 30 \\
\hline $\mathrm{Ml}-2$ & Species & 22 \\
& Species cf. & 32 \\
& Genera & 54 \\
\hline FLB & Species & 17 \\
& Species cf. & 21 \\
& Genera & 38 \\
\hline & Species & 7 \\
& Species cf. & 15 \\
\hline
\end{tabular}


The output for the provided CRACLE R-code includes the results of the parametric and non-parametric joint likelihoods (P-CRACLE and N-CRACLE), the ranges derived by "strict" CA ( $100 \%$ only), and the ranges derived from a "relaxed" (90\%) CA (Mosbrugger and Utescher, 1997) using the GBIF database observations and WorldClim as inputs for the 19 climate variables used by BIOCLIM (http://www.worldclim.org/bioclim; see Data Sheet S2 for full results). Of these climate variables, six climate variables from Harbert and Nixon (2015) verified against WorldClim were assessed in detail: Mean Annual Temperature (MAT), maximum temperature of warmest month (MAX), minimum temperature of the coldest month (MIN), Mean Annual Precipitation (MAP), precipitation of the wettest quarter (WET), and precipitation of the driest quarter (DRY). As per the original tests of the CA against fossil flora (Mosbrugger and Utescher, 1997), using all of the coexisting taxa produced nonoverlapping climate ranges. For this reason the strict (all data from all taxa) CA was not used, and further discussion refers to the CA method as proposed by Mosbrugger and Utescher (1997), which calculates the envelope in which the most taxa are able to coexist (referred to as the relaxed CA in code output). In addition, we investigated if removing non-woody taxa, as per Harbert and Nixon (2015), differed from our complete taxa list results by running CRACLE by woody species only.

\section{Dissimilarity in Vascular Plant Community and Climate}

In order to investigate whether the dissimilarity in community structure depends upon a dissimilarity in climate, we tested the relationship between climatic results and dissimilarity indices for the five sites. The lists of plant taxa identified across the CAA facilitate an investigation of the shared (beta) diversity between sites, and thus the similarity or dissimilarity of the floras. The use of dissimilarity indices suitable for paleontological applications, in this instance the Raup-Crick Dissimilarity Index, a weighted measure of community dissimilarity using Monte Carlo simulations (Raup and Crick, 1979; Chase et al., 2011), provide evidence with regard to the interconnectedness of the communities studied and the conditions in which they formed.

The Raup-Crick analysis was conducted separately on vascular plants at the level of species and species cf. for correlation with climate variables as was used for climate analysis (1:0, sites as rows, Data Sheet S3). The implementation follows Chase et al. (2011). Dendrograms of the Raup-Crick indices were generated using h-clust with agglomerative clustering using complete linkage (furthest-neighbor joining), and the Unweighted Pair Group Method with Arithmetic Averaging (UPGMA) in vegan (2.4-1) for R (Oksanen et al., 2015). Complete linkage is a conservative method, which tends to underestimate similarity between recognized clusters, whilst UPGMA is the more commonly applied method in paleoecology. The resulting patterns of clustering were then compared.

The difference in the six climate variables, pair-wise by site, was tested against the dissimilarity index results using the non-parametric Kendall's Tau. This approach was selected as a Shapiro-Wilk test resulted in a large number of non-normal distributions of variables and it produces more accurate $P$-values for small samples. Kendall's Tau was calculated using "corr.test" in psych (1.6.9) for $\mathrm{R}$ (Revelle, 2016). The species derived climate variables, and formed pairwise combinations, were tested against the species dissimilarity indices. The species cf. derived climate variables, and formed pairwise combinations, were tested against the species cf. derived dissimilarity indices. To understand if the results could be due to low statistical power, the climate estimates from species were examined for clustering by recursive partitioning using "rpart" (4.1.10) for R (Therneau et al., 2015) and compared to the clustering of dissimilarity indices from species. The basis of node branching was compared with results from a principal components analysis.

\section{RESULTS}

\section{Climate}

The warmest of all sites investigated in this study was BI, with the contribution to these higher temperatures relative to the other floras, more from warmer winter temperatures, than from warmer summer temperatures i.e., temperature of the coldest month was much warmer at BI, whereas temperature of the warmest month was only slightly warmer than the other sites (Figure 3, Data Sheet S2). This pattern of reduced thermal amplitude, with increased MAT is consistent with previous studies, and is evidence for the internal consistency of this method (e.g., Hernández Fernández, 2006; Hernández Fernández et al., 2007). The next warmest were MI-1, FLB, and MI-2, whilst BP had the coolest MAT estimates. WET and DRY were fairly consistent between sites and WET tended to approximate or be slightly higher than three times the precipitation of DRY. The variability in the MAP results between species and species $\mathrm{cf}$. for BI makes it difficult to compare the sites for this variable. The range of estimates suggest that this site is either approximately the same as MI-2, BP and FLB or considerably wetter.

Between the analyses conducted using species only, or species cf. identifications, DRY, WET, MAX, and MIN were consistent. For MAP MI-1, MI-2, and BP were similar, but FLB was drier when using species $\mathrm{cf}$. and precipitation at $\mathrm{BP}$ was nearly twice as high if species cf. is used. MAT was warmer with species $\mathrm{cf}$. for BI $\sim+2^{\circ} \mathrm{C}, \mathrm{MI}-2 \sim+1^{\circ} \mathrm{C}$, and $\mathrm{BP} \sim+0.5^{\circ} \mathrm{C}$; MI- 1 was very similar between species and species cf. and FLB was slightly cooler at its minimum bound, but barely at the maximum.

For genera level identifications, N-CRACLE results were so broad as to be uninformative (e.g., $-30^{\circ}$ to $+30^{\circ} \mathrm{C}$ ). The genera level results for P-CRACLE and CA were warmer than those derived from the species and species cf. list, which were, in turn warmer than estimates derived from species level identifications. Genera level P-CRACLE tended toward slightly drier results, but with variability between sites and between MAP, WET, and DRY.

\section{Dissimilarity vs. Climate}

The Raup-Crick analyses resulted in different clustering of communities (Figure 4, Table 2). The MI-1 flora clusters with BP and MI-2 with FLB by species, however, the clustering changes when analyzed using species cf. such that MI-1 clusters with FLB and MI-2 with BP. BI is always the most dissimilar 


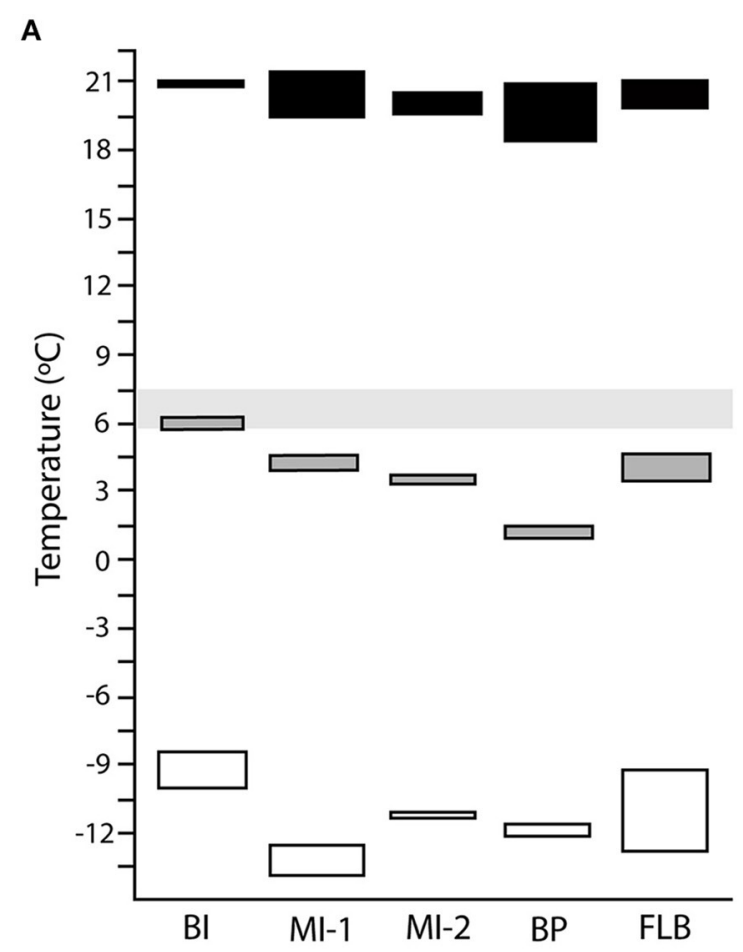

B

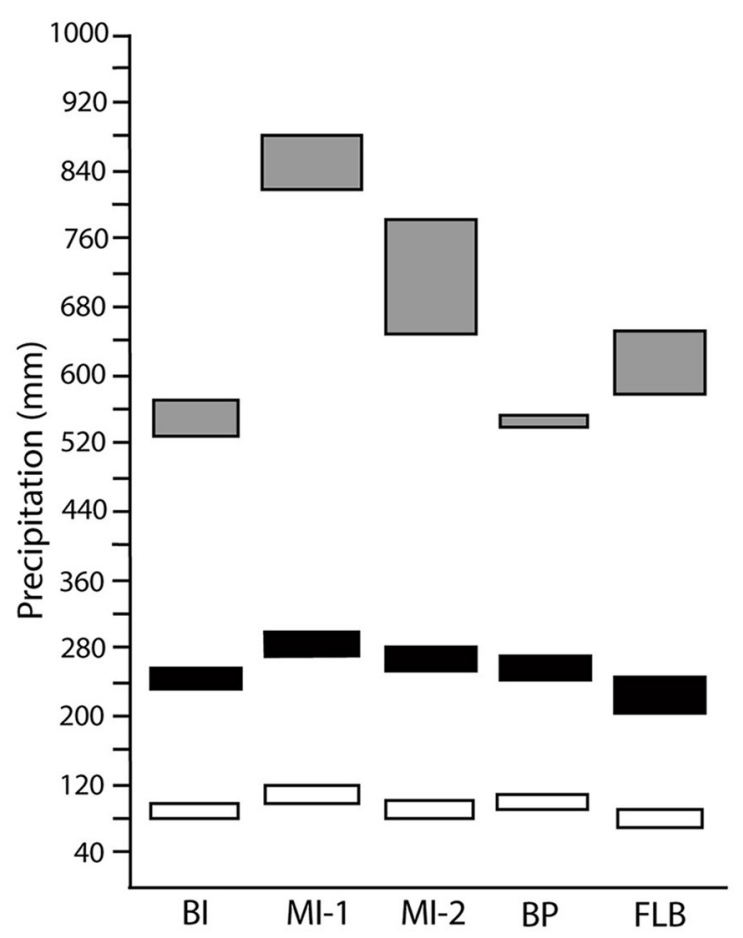

FIGURE 3 | Summary of temperature and precipitation reconstructions from species assemblages across sites. Temperature estimates (A), with mean annual temperature (gray), maximum temperature of warmest month (black), and minimum temperature of coldest month (white), where light gray shading indicates the global threshold for tree line. Precipitation estimates (B), with mean annual precipitation (gray), precipitation of the three wettest months (black) and the three driest months (white).

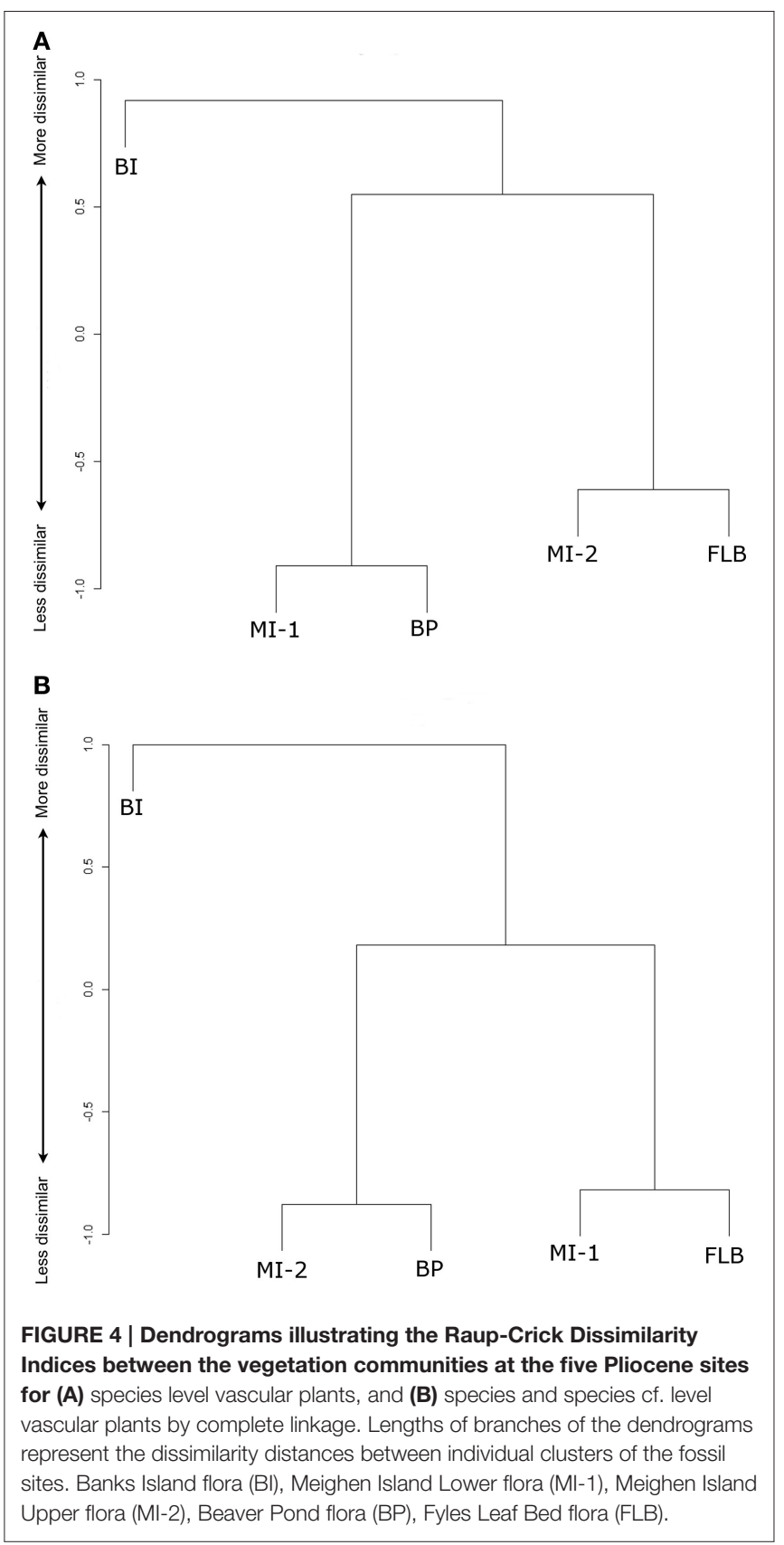

locality. Complete linkage clustering and UPGMA yielded similar hierarchical clustering patterns but changed the height of the bracket joining MI-2 and BP to MI-1, and FLB such that complete clustering reported a more positive value indicating a moderate dissimilarity between the two clusters, and UPGMA closer to 0 suggesting the distribution of species between the clusters was not distinguishable from the random draw of the Monte Carlo simulations. Dissimilarity in community assemblage did not correlate by rank with any climate variable or combination of climate variables tested with significance $(p<0.05)$, even though Banks Island was the most dissimilar in terms of species assemblage and had the highest MAT. Further investigation by 
TABLE 2 | Raup-Crick indices, pairwise by site, where -1 is the least dissimilar, 1 is the most dissimilar and 0 is not distinguishable from Monte Carlo simulations.

\begin{tabular}{llllll}
\hline Taxa category compared & Site/site & BI & MI-1 & MI-2 & BP \\
\hline Species level vascular taxa & Ml-1 & 0.75 & & & \\
& Ml-2 & 0.92 & 0.02 & & \\
& BP & 0.58 & -0.91 & -0.18 & \\
& FLB & -0.01 & -0.36 & -0.61 & 0.55 \\
\hline Species cf. level vascular taxa & Ml-1 & 0.64 & & & \\
& Ml-2 & 1 & 0.18 & & \\
& BP & 0.86 & -0.84 & -0.88 & \\
& FLB & 0.55 & -0.82 & -0.72 & -0.08 \\
\hline
\end{tabular}

For presence/absence tables, shared taxa count and gamma diversity, see Data Sheet S3.

examining the clustering of the climate data, showed that the upper and lower bounds of mean annual temperature made the largest contributions to clustering of the sites by climate, and that these clusters were not of the same structure as the clustering of sites by dissimilarity (Data Sheet S4).

\section{DISCUSSION}

\section{Comparisons to Previous Estimates}

The majority of previous climate estimates have focused on a key site for vertebrate fossils, Beaver Pond. The difference between the MAT and MAX estimates for $\mathrm{BP}$ and previous estimates (Elias and Matthews, 2002; Ballantyne et al., 2006, 2010; Csank et al., 2011a,b), including those derived using related methods (Ballantyne et al., 2010), are relatively small, often insignificant as they fall within error. Previous MAT estimates from tetraether, $0.6^{\circ} \mathrm{C} \pm 5$, and paleovegetation, $-0.4^{\circ} \mathrm{C} \pm 4.1$ methods are within the range of our estimates by N-CRACLE, for both species $0.8-$ $1.5^{\circ} \mathrm{C}$, and species cf. $1.5-1.8^{\circ} \mathrm{C}$, and $\mathrm{CA},-1.7-5.6^{\circ} \mathrm{C}$ and $0.5-$ $5.7^{\circ} \mathrm{C}$. Ballantyne et al.'s (2010) tree ring isotopes, at $-0.5^{\circ} \mathrm{C} \pm$ 1.9 , are within the range estimates for species both by N-CRACLE and CA.

Csank et al. (2011a) expanded on Ballantyne et al.'s (2010) study at BP, analyzing $\sim 250$ rings and using a mechanistic model to estimate temperature from the isotopic signature. The MAT estimates from Csank et al. (2011a) $-1.4^{\circ} \mathrm{C} \pm 4.0$, include the range of the CRACLE interval, and overlap with the CA. Growing season (June-July) temperature estimates, $15.8^{\circ} \mathrm{C} \pm 5.0$, were comparable to our species and species cf. MAX interval, $18.2-21.1^{\circ} \mathrm{C} / \sim 20^{\circ} \mathrm{C}$, when accounting for the broader window for which the average is calculated. If Csank et al.'s (2011a) and Ballantyne et al.'s (2010) estimates are considered relatively cooler, despite being within error, it may be explained by the uncertainty regarding the isotopic composition of source water leading to potential biases in the these estimates (Sugimoto et al., 2002). For example, a cooler estimate could reflect high use of snow or permafrost meltwater, or magnification of the winter precipitation signal in groundwater. This bias likely has a greater effect on fen environments as posited for BP (Csank et al., 2011a).
The mollusk growth season (May to September) temperature of surface water from Csank et al. (2011b), using conventional and clumped isotopic approaches, resulted in estimates of $14.2^{\circ} \mathrm{C} \pm 1.3$ and $10.2^{\circ} \mathrm{C} \pm 1.4$, each with their own caveats. Among these estimates, the upper limits of temperature sampled across the whorl were comparable to our MAX estimates (18.5-21 $\left.{ }^{\circ} \mathrm{C}\right)$. However, isotopic estimates of mollusk growing season temperatures are not necessarily comparable because the paleovegetation records above surface air temperatures, whereas the mollusk shells record surface freshwater temperatures, which are expected to be cooler by at least $1^{\circ} \mathrm{C}$ (Fricke and Wing, 2004). Air temperature explains only $\sim 38 \%$ of maximum summer surface temperature in a modern boreal lake system (Keller, 2007), which potentially explains the relatively cooler temperature estimated by Csank et al. (2011b). In addition to this, and source water composition, other characteristics of the lake, such as water clarity, may also be important for reconciling differences of lake water and surface air temperatures (e.g., Snucins and Gunn, 2000).

Elias and Matthews (2002) used mutual range methods for beetle fauna to estimate MAX and MIN for BI, MI (stratigraphic positions relative to the marine sequence, unknown) and BP. They also found little difference between the sites in terms of MAX (BI $13.5^{\circ} \mathrm{C}$, BP $12.4^{\circ} \mathrm{C}$, MI $12.912 .8 \quad 12.6^{\circ} \mathrm{C}$ ), however, the estimates are around $7^{\circ} \mathrm{C}$ lower than presented here. MIN estimates were more variable across the archipelago $\left(\mathrm{BI}-21^{\circ} \mathrm{C}\right.$, $\mathrm{BP}-26.6^{\circ} \mathrm{C}$, MI $-21^{\circ} \mathrm{C}-27.3^{\circ} \mathrm{C}-26.9^{\circ} \mathrm{C}$ ), and were $10-$ $15^{\circ} \mathrm{C}$ colder than our estimates, but were presented with less confidence than the MAX range (Elias and Matthews, 2002). These estimates point to a clear disagreement between estimates from paleovegetation and isotopic records as compared to paleofaunal mutual range estimates. Warmer estimates from paleovegetation and cooler estimates from the beetle mutual range methods have also been identified at the Late Pliocene Lost Chicken Mine locality in Alaska, at which the presence of Sambucus suggests January temperatures $10-15^{\circ} \mathrm{C}$ warmer than today, but the beetle mutual range method suggested winter minima only $2.3^{\circ} \mathrm{C}$ warmer than modern (Matthews et al., 2003). This discrepancy may be due to incomplete knowledge of beetle thermal and distributional ranges given that some species have been observed beyond the official ranges used in the mutual range methods (J. V. Matthews, Jr., Pers. Obs.) or relative insensitivity to minimum temperatures due to behavioral avoidance. This apparently common, if not systematic, difference between floral and faunal estimate warrants further investigation.

\section{Comparisons to Modern}

The site that is the most distant from the others (BI), was warmest according to N-CRACLE (Figure 3, Data Sheet S2). BI was $\sim 20^{\circ} \mathrm{C}$ warmer than present (see Table 3 for present values), and the more northerly Meighen Island sites were $\sim 25^{\circ} \mathrm{C}$ warmer, FLB and BP sites $\sim 23^{\circ} \mathrm{C}$ and $\sim 20^{\circ} \mathrm{C}$ warmer than present. The modern difference in MAT between the Eureka Climate Station on Ellesmere Island $\left(-18.8^{\circ} \mathrm{C}\right)$, and Sachs Harbour Climate Station on Banks Island $\left(-12.8^{\circ} \mathrm{C}\right)$, is $6^{\circ} \mathrm{C}$ (Environment Canada, 2015). The terrestrial temperature gradient from pole to equator is known to be lower during the Pliocene (Salzmann et al., 
TABLE 3 | Modern climate values (1960-1990) for closest coordinates to the sites using WorldClim 30 second interpolated grid climatologies version 1.4 (http://www.worldclim.org/).

\begin{tabular}{|c|c|c|c|c|c|c|c|}
\hline Site & MAT $\left({ }^{\circ} \mathrm{C}\right)$ & $\operatorname{MAX}\left({ }^{\circ} \mathrm{C}\right)$ & $\operatorname{MIN}\left({ }^{\circ} \mathrm{C}\right)$ & MAP (mm) & WET (mm) & DRY (mm) & WorldClim datapoint coordinate \\
\hline $\mathrm{Bl}$ & -15.2 & 7.9 & -35.4 & 130 & 67 & 10 & $73^{\circ} \mathrm{N} 120^{\circ} \mathrm{W}$ \\
\hline $\mathrm{Ml}-1$ & -20.9 & 4.1 & -42.5 & 98 & 55 & 7 & $80^{\circ} \mathrm{N} 99^{\circ} \mathrm{W}$ \\
\hline Ml-2 & -20.9 & 4.1 & -42.5 & 98 & 55 & 7 & $80^{\circ} \mathrm{N} 100^{\circ} \mathrm{W}$ \\
\hline $\mathrm{BP}$ & -18.6 & 7.1 & -39.7 & 104 & 50 & 12 & $79^{\circ} \mathrm{N} 82^{\circ} \mathrm{W}$ \\
\hline FLB & -18.6 & 7.1 & -39.7 & 104 & 50 & 12 & $79^{\circ} \mathrm{N} 83^{\circ} \mathrm{W}$ \\
\hline
\end{tabular}

2013). Our results suggest the Pliocene temperature gradient may be about half of modern in this region. Under present-day conditions, the difference in temperature between the northerly sites (MI-1, MI-2, BP, and FLB) and BI, is exacerbated by the northern sites' proximity to the thickest Arctic perennial sea ice. Strong cooling of the terrestrial sites occurs directly from the high sea ice, and due to high surface albedo depressing their modern temperatures compared to other locations at the same latitude (e.g., $-16.5^{\circ} \mathrm{C}$, Vavilov Climate Station, Severnaya Zemlya; Bassford et al., 2006). A lack of or large reduction in permanent sea ice as suggested for the Pliocene (Ballantyne et al., 2013) may have exaggerated the reduction of the temperature gradient between $\mathrm{BI}$ and the higher latitude sites. However, when comparing the results from these sites it is necessary to note that although they are all Pliocene, the resolution of dating (see Dating Constraints and Uncertainties) cannot distinguish if they were roughly coeval or represent cooler and warmer periods, perhaps Pliocene glacial and interglacial periods. If so, BP, for instance, may be from a cooler period than its geographically near neighbors.

All sites are currently located in a very dry region $(98-130 \mathrm{~mm}$ MAP). However, as the geography of the CAA was significantly different during the Pliocene compared to present (Rybczynski et al., 2013), and shorelines advanced and retreated within the time periods represented by these flora (as evidenced by the marine layer that separates MI-1 and MI-2; Fyles et al., 1991), the effect on the precipitation within the region is complex to predict. While, as expected, the analysis estimated precipitation was much higher than today at all sites, the differences in precipitation between the sites are difficult to integrate into our conceptual model of the region given current understanding of the age of the sites and geography of the region at the time of deposition.

\section{Comparisons to Pliocene Climate Models}

The most comprehensive comparison of Pliocene climate models, between each other and with proxy data, is the Pliocene Modelling Intercomparison Project (Hill et al., 2014). Strongly amplified polar warming despite moderate atmospheric $\mathrm{CO}_{2}$ levels is a notable feature of the time slab studied (Miller et al., 2010; Haywood et al., 2016). Although the models do produce polar amplification, proxy data suggests these are underestimates of the true level of warming (Melles et al., 2012). Indeed, temperature underestimates range from a few to $20^{\circ} \mathrm{C}$ in northern high latitudes in models such as HadCM3, MIROC, and CCSM4 (Haywood et al., 2010, 2013, 2016). The temperature estimates presented here largely agree with previous estimates (see Comparisons to Previous Estimates), or are warmer than those (Elias and Matthews, 2002). As a result, the addition of this new proxy data will exacerbate the observed proxy-model mismatch for the northern high latitudes. A caveat of comparing our results to the model data outputs is that, although many of our sites' estimates overlap the time slab of these studies (3.264-3.025 Ma), they cannot be precisely dated to this time and thus orbital cycles, variations in atmospheric $\mathrm{CO}_{2}$, changes in ocean gateways, and many other dynamic processes with large impacts on climate, may generate considerable differences (Feng et al., in press). Additionally, the terrestrial vegetation record for the Pliocene High Arctic may be biased to thermal optima in interglacial periods due to better conditions for higher plant productivity.

\section{Observations on CRACLE}

It is often necessary in paleoclimatology to use higher levels of identifications where species level is not known, the species is not extant, or may be misidentified as an extant species from limited materials. Given that CRACLE is a recently developed method, and the substitution of genera for extinct species has been criticized for related methods (Grimm and Potts, 2016), we investigated potential concerns in applying the method to different taxa level identifications by extending CRACLE to nonwoody species, and using genera level identifications.

Harbert and Nixon (2015) limited their analysis to woody taxa only, but suggest that this is not a necessary limitation on the method. We hypothesized that species level CRACLE estimates would not differ significantly between those based on all vascular plants, and that based on trees and shrubs only. This would be of benefit as not all fossil flora are characterized by abundant and taxonomically rich woody species. Although our hypothesis is largely supported, there are exceptions. The estimates for MAP tend to be somewhat wetter for woody taxa only compared with all species, ranging from a non-discernable difference at FLB to within $50 \mathrm{~mm}$ for MI-1, MI-2, and BI, and the largest difference of $\sim 400 \mathrm{~mm}$ at BP (Data Sheet S2). Estimates for woody taxa only were also warmer at BP, thus choosing only woody taxa or all vascular species results in a large difference in climate estimates at this site. Overall the difference between woody species only and all species was smaller than the difference between species and species cf. estimates for temperature, but not for precipitation.

The further back in deep time the fossil locality investigated was deposited, the more often identifications can only be made 
to a genus level, and the ranges of modern species from the same genus have often been used as nearest living analogs. It was predicted that the genus level estimates would be warmer than species level predictions due to the latitudinal biodiversity gradient, biasing diversity within a genera toward lower latitudes. This was supported for P-CRACLE and CA for MAT, MAX, and MIN. The genera level estimations for N-CRACLE are massively wide as to be uninformative e.g., BP MAT. $-27^{\circ} \mathrm{C}$ to $30^{\circ} \mathrm{C}$. These results suggests that the use of genera level identifications of fossil taxa are at best biased by global patterns of diversity in the case of the CA and P-CRACLE temperature estimates, if not entirely uninformative as in N-CRACLE, when applied to mutual range methods. Targeted investigation of this effect over a greater latitudinal range would benefit the field of study, but investigators of high latitudes should be especially cautious when interpreting these results.

Comparing precipitation estimates, the N-CRACLE estimates remain uninformatively wide. Within P-CRACLE, DRY estimates are drier for genera level identifications than all other results, and WET are in the same general range. The MAP estimates were mixed. FLB fell within the range of estimates from the other taxa for P-CRACLE, while the other sites were slightly to somewhat drier. This bias appears weaker than the temperature bias, conforming to the results of studies such as Moles et al. (2014) and Butterfield and Munson (2016), which show a stronger association of plant functional traits with temperature than precipitation, if, as posited by phylogenetic niche conservatism (e.g., Donoghue, 2008), these traits are often conserved amongst higher taxonomic rankings.

Harbert and Nixon (2015) suggest CRACLE, and other taxon-based mutual range methods, are most applicable and precise for floras closer to modern (Quaternary) due to sensitivity to extinctions, whilst climates in deep time are more accurately estimated by methods such as leaf foliar physiognomic analyses, which are based on physiological adaptations to climate and do not necessarily require knowledge of phylogenetic relatedness to modern flora ( $\mathrm{Li}$ et al., 2016). However, foliar physiognomic analyses are complicated by their own biases including taphonomic (e.g., Greenwood, 1992, 2005; Burnham et al., 2001; Kowalski and Dilcher, 2003; Spicer et al., 2011) and methodological (e.g., Jordan, 2011; Milla and Reich, 2011) concerns. The time period from this study lies at the intersection of the projected utility of these two families of methods, thus application of foliar physiognomy to validate CRACLE estimates of climate in the Pliocene may provide valuable insight to disentangle how ecosystem assembly and individual physiognomy respond to climate.

It is evident that the magnitude of the range between the upper and lower boundary for each of the climate estimates given varied between sites and between climate variables within a site (Figure 3). A narrow range estimate of the climatic inferences reflects that there is a narrow range for that climate variable in which those taxa are most likely to coexist. Harbert and Nixon (2015) state that the estimate is influenced most by the most narrowly distributed taxa, and thus the narrower estimates may reflect taxa included at those sites with narrow climate tolerances. However, Harbert and Nixon (2015) did not test the effect of non-overlapping taxa on the range of the climate estimates produced by CRACLE. As all estimates herein have non-overlapping results in the strict implementation of the coexistence approach (See Data Sheet S2), this is an alternative source of influence to be investigated. We found the relationship between the number of taxa at the site or degree of non-overlap of the strict coexistence estimates, and the narrowness of the climate range produced for each variable was unclear. Application of this method to the past would benefit from a dedicated study of the impacts of non-overlapping ranges on climate estimates.

\section{Reconciling Similar Climates and Dissimilar Communities}

Our analysis suggests that other factors, in addition to climate, may drive the patterns of assemblage of vascular taxa within the CAA during the Early to mid-Pliocene. Within the limits of the range in climate within the region, either the impact of climate is more complex than captured, or other biotic and abiotic factors not measured here contribute a stronger control, or some combination of the two.

Previous studies (e.g., Fyles et al., 1994) have considered the BI flora to represent a boreal forest ecosystem, while growth rings from wood on Meighen Island showed indications of being near tree line. Kuc (1974) and Matthews (1987) also considered the macroflora of Meighen Island indicative of sparse, although diverse (Fyles et al., 1991), conifers at forest-tundra boundary. Matthews and Fyles (2000) describe the BP flora to be largely composed of plants suggestive of an open larch dominated foresttundra environment containing an extinct species of larch (Larix groenlandii). A more detailed examination of the FLB flora is yet to be published, however it is currently also considered to be located in a forest-tundra ecosystem, featuring the same extinct species of larch (L. groenlandii), abundant leaves of dwarf and shrub birch (Betula spp.) and shrubs of mountain avens (Dryas octopetala) not currently found in the CAA (Matthews and Telka, Pers. Obs.).

Most studies of tree line have focused on regional peculiarities or particular species, rather than generalizable perspectives (Körner and Paulsen, 2004), however at least two global studies have been conducted. In a field study of soil temperature and tree line in modern systems, Körner and Paulsen (2004) found tree line occurs around $6.7^{\circ} \mathrm{C}( \pm 0.8 S D)$ globally, and that daily means of air and soil temperature are almost the same, between 6 and $7^{\circ} \mathrm{C}$. A later study by the same authors (Paulsen and Körner, 2014) developed a model for predicting global tree line, and validated it against satellite observations of tree line position globally. This study also found the mean annual temperature, in this study $\sim 6.4^{\circ} \mathrm{C}$, to be a key explanatory variable, along with minimum growth days of 94 .

Confidence in applying modern climate tree line boundaries to the past is dependent on an understanding of the causal relationship between temperature and growth form. Many proposed mechanisms for the constant soil temperaturetree line relationship center on soil decomposition rates, low nutrient mineralization rates and their assimilation by trees (See discussion in Scott et al., 1997). This is supported by 
evidence that photosynthetic rate is not limiting compared with decreased utilization of photosynthetic products in response to low temperatures (Grace et al., 2002). However, these hypotheses alone do not explain the loss of trees specifically, while low shrubs may thrive. Observations have shown that for a given ambient temperature taller flora experience near ambient air temperatures and cooler soil temperatures than do low-statured flora, due to the low flora's aerodynamic decoupling from ambient temperatures above, to form a microclimate around themselves and their soil (Grace, 1988; Scherrer and Körner, 2011). Because trees are not as efficient as low statured plants at generating a warmer microclimate for themselves they are more immediately impacted by lower nutrient acquisition and assimilation rates as a result of low temperature. This suggests a physical and physiological explanation for tree line that should hold if applied to the past.

Combined with the macrofossil interpretations above, this suggests the BI flora was just within this tree line temperature threshold, while our four more northerly sites were outside this range. Thus, the relatively small difference in temperature may be within a critical range to drive the stable and large dissimilarity in community assembly only between BI and the MI- 1, MI-2, $\mathrm{BP}$, and FLB cluster, while non-climate influences were stronger drivers of dissimilarity within the MI-1, MI-2, BP, FLB cluster.

The habitat preferences of the species that differ between MI1, MI-2, BP, and FLB provide evidence for how abiotic differences may have influenced the composition of these communities. For example, taxa at the Meighen Island sites that are known for their role as pioneers include Alnus alnobetula, A. incana, and Betula populifolia, none of which were found at BP, which was likely stable for the duration of peat deposition estimated at 49,000 years (Mitchell et al., 2016). Thus, the stage of the vegetation post-disturbance, and any time averaging of the assemblages may also impact the composition. The dominance of larch $(L$. groenlandii) at BP and FLB compared to Meighen Island where larch is present but does not dominate, may reflect differences in soils. For example cation, nitrogen and phosphorus availability and water table depth were key factors in a model of evergreendeciduous-evergreen dominance along mineral supply gradients in boreal peatlands (Givnish, 2002).

Despite these differences, the presence of taxa with habitat preference for wetlands or stream sides is common to all sites. This was confirmed as a Raup-Crick analysis run on only non-wetland species or non-wetland species cf. showed that all sites showed increased dissimilarity except BI, which became either more similar to FLB, or more similar to FLB and MI-1, respectively, although still highly dissimilar according to the index (Data Sheet S3). This presence of taxa with habitat preference for wetlands or stream sides may represent taphonomic bias toward preservation of plant materials in those environments. Occasional exceptions to this pattern, such as the presence of D. octopetala-a taxa more commonly found on dry and rocky sites, suggest transport either of the whole assemblage from multiple sources, deposited in one locality, or transport of the non-wetland components into the wetland system, where they were preserved-an interpretation favored by suitable conditions for preservation within wetland systems.
Thus, we consider dissimilarity to be driven primarily by the temperature threshold for tree line where that is crossed, but by other abiotic factors where the compared sites are below that threshold. Low dissimilarity between the four northern sites is explained by bias toward preservation of wetlands, similarity of climate and the proposed paleogeography of the region at the time featuring a continuous landmass where the archipelago is now incised, thus allowing floral and faunal exchange.

\section{CONCLUSIONS}

Comparisons to previous climate estimates from isotopic and floral methods show agreement with the CRACLE for temperature estimates where comparable. This result lends support to the applicability of this method to Pliocene fossil floral communities, with some caveats. These include that particular attention should be paid to the level of taxonomic identification.

Multi-proxy methods are a common approach to exploring the inherent uncertainties in estimation of climate in deep time. The application of additional methods to these floras may provide more confidence in the estimates, while providing previously unknown precipitation estimates. The application of a community-based approach such as CRACLE, helps ensure that the multiple proxies used are not being affected by the same confounding effects, as taphonomic biases affect organisms and their parts, in different ways.

Although we used a community-based approach to climate reconstruction, community dissimilarity was not statistically explained by climate. Climate is a strong influence on community assembly where the difference in climate is large or important ecological thresholds are crossed, however within climate brackets, biotic or abiotic factors in the environment partition taxa that are otherwise able to share the same climate space, thus, dissimilarity of community does not necessitate different climate conditions at that locality. This serves as a reminder to be mindful of the large impact of non-climatic abiotic and biotic factors when predicting future ranges of communities under different climate conditions from the present.

\section{AUTHOR CONTRIBUTIONS}

TF: Substantial contribution to the conception or design of the work, analysis and interpretation of data; Data Acquisition; Drafting the work and revising it critically for important intellectual content; Final approval of the version to be published; Agreement to be accountable for all aspects of the work in ensuring that questions related to the accuracy or integrity of the work are appropriately investigated and resolved. RF: Substantial contribution to the interpretation of data; critically revising the work; Final approval of the published version; Agreement to be accountable for all aspects of the work. AT and JM: Data Acquisition; Drafting the work and revising it critically; Final approval of the published version; Agreement to be accountable for all aspects of the work. AB: Substantial contribution to the conception or design of the work and interpretation of data; Drafting the work and revising it critically for important 
intellectual content; Final approval of the version to be published; Agreement to be accountable for all aspects of the work.

\section{ACKNOWLEDGMENTS}

The authors would like to thank Robert Harbert for assistance with the CRACLE code, Brady Allred for access to computing resources, and Annie Cooper for assisting with statistics. David Greenwood and Natalia Rybczynski contributed to early discussions of this work. Two reviewers provided feedback on an earlier version of this work, and the study is much

\section{REFERENCES}

Ballantyne, A. P., Axford, Y., Miller, G. H., Otto-Bliesner, B. L., Rosenbloom, N., and White, J. W. C. (2013). The amplification of Arctic terrestrial surface temperatures by reduced sea-ice extent during the Pliocene. Palaeogeogr. Palaeoclimatol. Palaeoecol. 386, 59-67. doi: 10.1016/j.palaeo.2013.05.002

Ballantyne, A. P., Greenwood, D. R., Sinninghe Damsté, J. S., Csank, A. Z., Eberle, J. J., and Rybczynski, N. (2010). Significantly warmer Arctic surface temperatures during the Pliocene indicated by multiple independent proxies. Geology 38, 603-606. doi: 10.1130/G30815.1

Ballantyne, A. P., Rybczynski, N., Baker, P. A., Harington, C. R., and White, D. (2006). Pliocene Arctic temperature constraints from the growth rings and isotopic composition of fossil larch. Palaeogeogr. Palaeoclimatol. Palaeoecol. 242, 188-200. doi: 10.1016/j.palaeo.2006.05.016

Bassford, R. P., Siegert, M. J., Dowdeswell, J. A., Oerlemans, J., Glazovsky, A. F., and Macheret, Y. Y. (2006). Quantifying the mass balance of ice caps on Severnaya Zemlya, Russian high Arctic. I: climate and mass balance of the Vavilov ice cap. Arctic Antarct. Alp. Res. 38, 1-12. doi: 10.1657/15230430(2006)038[0001:QTMBOI]2.0.CO;2

Brigham-Grette, J., and Carter, L. (1992). Pliocene marine transgressions of northern Alaska: circumarctic correlations and paleoclimatic interpretations. Arctic 45, 74-89. doi: 10.14430/arctic1375

Brigham-Grette, J., Matthews, J., and Marincovich, J. (1987). "Age and paleoenvironmental significance of Arctic in the Neogene Beaufort Fm on Meighen Island, Queen Elizabeth Islands, Canada," Abstract Retrieved from 16th Arctic Workshop Abstracts (Edmonton), 12-14.

Brigham-Grette, J., Melles, M., Minyuk, P., Andreev, A., Tarasov, P., DeConto, R., et al. (2013). Pliocene warmth, polar amplification, and stepped Pleistocene cooling recorded in NE Arctic Russia. Science 340, 1421-1427. doi: $10.1126 /$ science. 1233137

Burnham, R. J., Pitman, N. C., Johnson, K. R., and Wilf, P. (2001). Habitat-related error in estimating temperatures from leaf margins in a humid tropical forest. Am. J. Bot. 88, 1096-1102. doi: 10.2307/2657093

Butterfield, B. J., and Munson, S. M. (2016). Temperature is better than precipitation as a predictor of plant community assembly across a dryland region. J. Veg. Sci. 27, 938-947. doi: 10.1111/jvs.12440

Chase, J. M., Kraft, N. J. B., Smith, K. G., Vellend, M., and Inouye, B. D. (2011). Using null models to disentangle variation in community dissimilarity from variation in $\alpha$-diversity. Ecosphere 2, 1-11. doi: 10.1890/ES10-00117.1

Csank, A. Z., Patterson, W. P., Eglington, B. M., Rybczynski, N., and Basinger, J. F. (2011a). Climate variability in the Early Pliocene Arctic: Annually resolved evidence from stable isotope values of sub-fossil wood, Ellesmere Island, Canada. Palaeogeogr. Palaeoclimatol. Palaeoecol. 308, 339-349. doi: 10.1016/j.palaeo.2011.05.038

Csank, A. Z., Tripati, A. K., Patterson, W. P., Eagle, R. A., Rybczynski, N., Ballantyne, A. P., et al. (2011b). Estimates of Arctic land surface temperatures during the early Pliocene from two novel proxies. Earth Planet. Sci. Lett. 304, 291-299. doi: 10.1016/j.epsl.2011.02.030

Davies, N. S., Gosse, J. C., and Rybczynski, N. (2014). Cross-bedded woody debris from a Pliocene forested river system in the high Arctic: beaufort Formation, Meighen Island, Canada. J. Sediment. Res. 84, 19-25. doi: 10.2110/jsr.2014.5 improved as a result. We would also like to thank the two reviewers of this paper whose advice further improved the clarity and completeness of this manuscript. This work was funded by NSF Division of Polar Programs Grant 1418421 to $\mathrm{AB}$.

\section{SUPPLEMENTARY MATERIAL}

The Supplementary Material for this article can be found online at: http://journal.frontiersin.org/article/10.3389/fevo. 2017.00019/full\#supplementary-material

Devaney, J. R. (1991). Clastic sedimentology of the beaufort formation, Prince Patrick island, Canadian arctic islands: late tertiary sandy braided river deposits with woody detritus beds. Arctic 44, 206-216. doi: 10.14430/arctic1540

Donoghue, M. J. (2008). A phylogenetic perspective on the distribution of plant diversity. Proc. Natl. Acad. Sci. 105(Suppl. 1), 11549-11555. doi: $10.1073 /$ pnas.0801962105

Elias, S. A., and Matthews J. V. Jr. (2002). Arctic North American seasonal temperatures from the latest Miocene to the early Pleistocene, based on mutual climatic range analysis of fossil beetle assemblages. Can. J. Earth Sci. 39, 911-920. doi: 10.1139/e01-096

Environment Canada (2015). Canadian Climate Normals and Averages Database. 22/09/2015.

Fedorov, A. V., Brierley, C. M., Lawrence, K. T., Liu, Z., Dekens, P. S., and Ravelo, A. C. (2013). Patterns and mechanisms of early Pliocene warmth. Nature 496, 43-49. doi: 10.1038/nature12003

Feng, R., Otto-Bliesner, B., Fletcher, T., Tabor, C., Ballantyne, A., and Brady, E. (in press). Amplified late Pliocene terrestrial warmth in northern high latitudes from greater radiative forcing and closed Arctic ocean gateways. Earth Planet. Sci. Lett. doi: 10.1016/j.epsl.2017.03.006

Fletcher, T., Brown, K., Warden, L., Csank, A., Feng, R., Higuera, P., et al. (2016). "Climate-vegetation-fire interactions: pieces in the Pliocene polar puzzle," in Abstract Retrieved from 49th Fall Meeting of the American Geophysical Union Abstracts (San Francisco, CA).

Fricke, H. C., and Wing, S. L. (2004). Oxygen isotope and paleobotanical estimates of temperature and $\delta 18 \mathrm{O}$-latitude gradients over North America during the early Eocene. Am. J. Sci. 304, 612-635. doi: 10.2475/ajs.304. 7.612

Fyles, J. G. (1990). Beaufort formation (late tertiary) as seen from Prince Patrick island, Arctic Canada. Arctic 43, 393-403. doi: 10.14430/arctic1632

Fyles, J. G., Hills, L. V., Matthews, J. V., Barendregt, R., Baker, J., Irving, E., et al. (1994). Ballast brook and beaufort formations (late Tertiary) on Northern banks island, Arctic Canada. Quat. Int. 22, 141-171. doi: 10.1016/1040-6182(94)90010-8

Fyles, J. G., Marincovich, L. Jr., Matthews, J. V. Jr., and Barendregt, R. (1991). Unique mollusc find in the beaufort formation (Pliocene) on Meighen Island, Arctic Canada. Geol. Surv. Can. Curr. Res. B 91, 105-112. doi: 10.4095/ 132552

Givnish, T. J. (2002). Adaptive significance of evergreen vs. deciduous leaves: solving the triple paradox. Silva Fenn. 36, 703-743. doi: 10.14214/sf.535

Gladenkov, A. Y., Oleinik, A. E., Marincovich, L. Jr., and Barinov, K. B. (2002). A refined age for the earliest opening of Bering strait. Palaeogeogr. Palaeoclimatol. Palaeoecol. 183, 321-328. doi: 10.1016/S0031-0182(02)00249-3

Grace, J. (1988). 3. Plant response to wind. Agric. Ecosyst. Environ. 22, 71-88. doi: 10.1016/0167-8809(88)90008-4

Grace, J., Berininger, F., and Nagy, L. (2002). Impacts of climate change on the tree line. Ann. Bot. 90, 537-544. doi: 10.1093/aob/mcf222

Greenwood, D. R. (1992). Taphonomic constraints on foliar physiognomic interpretations of late Cretaceous and tertiary palaeoeclimates. Rev. Palaeobot. Palynol. 71, 149-190. doi: 10.1016/0034-6667(92)90161-9

Greenwood, D. R. (2005). Leaf margin analysis: taphonomic constraints. Palaios 20, 498-505. doi: 10.2110/palo.2004.P04-58 
Grimm, G. W., and Potts, A. J. (2016). Fallacies and fantasies: the theoretical underpinnings of the coexistence approach for palaeoclimate reconstruction. Clim. Past 12, 611-622. doi: 10.5194/cp-12-611-2016

Harbert, R. S., and Nixon, K. C. (2015). Climate reconstruction analysis using coexistence likelihood estimation (CRACLE): a method for the estimation of climate using vegetation. Am. J. Bot. 102, 1277-1289. doi: 10.3732/ajb.1400500

Haywood, A. M., Dowsett, H. J., and Dolan, A. M. (2016). Integrating geological archives and climate models for the mid-Pliocene warm period. Nat. Commun. 7:10646. doi: $10.1038 /$ ncomms 10646

Haywood, A. M., Dowsett, H. J., Otto-Bliesner, B., Chandler, M. A., Dolan, A. M., Hill, D. J., et al. (2010). Pliocene Model Intercomparison Project (PlioMIP): experimental design and boundary conditions (Experiment 1). Geosci. Model Dev. 3, 227-242. doi: 10.5194/gmd-3-227-2010

Haywood, A. M., Hill, D. J., Dolan, A. M., Otto-Bliesner, B. L., Bragg, F., Chan, W. L., et al. (2013). Large-scale features of Pliocene climate: results from the Pliocene model intercomparison project. Clim. Past 9, 191-209. doi: 10.5194/cp-9-191-2013

Hernández Fernández, M. (2006). Rodent paleofaunas as indicators of climatic change in Europe during the last 125,000 years. Quat. Res. 65, 308-323. doi: 10.1016/j.yqres.2005.08.022

Hernández Fernández, M., Sierra, M. Á. Á., and Peláez-Campomanes, P. (2007). Bioclimatic analysis of rodent palaeofaunas reveals severe climatic changes in Southwestern Europe during the Plio-Pleistocene. Palaeogeogr. Palaeoclimatol. Palaeoecol. 251, 500-526. doi: 10.1016/j.palaeo.2007.04.015

Hijmans, R. J., Cameron, S. E., Parra, J. L., Jones, P.G., and Jarvis, A. (2005). Very high resolution interpolated climate surfaces for global land areas. Int. J. Climatol. 25, 1965-1978. doi: 10.1002/joc.1276

Hill, D. J., Haywood, A. M., Lunt, D. J., Hunter, S. J., Bragg, F. J., Contoux, C., et al. (2014). Evaluating the dominant components of warming in Pliocene climate simulations. Clim. Past 10, 79-90. doi: 10.5194/cp-10-79-2014

Jansen, E., Overpeck, J., Briffa, K. R., Duplessy, J. C., Joos, F., Masson-Delmotte, V., et al. (2007). "Palaeoclimate," in Climate Change 2007: The Physical Science Basis. Contribution of Working Group I to the Fourth Assessment Report of the Intergovernmental Panel on Climate Change, eds S. S. D. Qin, M. Manning, Z. Chen, M. Marquis, K. B. Averyt, M. Tignor and H. L. Miller (Cambridge, UK; New York, NY: Cambridge University Press).

Jordan, G. J. (2011). A critical framework for the assessment of biological palaeoproxies: predicting past climate and levels of atmospheric $\mathrm{CO} 2$ from fossil leaves. New Phytol. 192, 29-44. doi: 10.1111/j.1469-8137.2011.03829.x

Kaufman, D., Farmer, G., Miller, G., Carter, L., and Brigham-Grette, J. (1990). "Strontium isotope dating of Upper Cenozoic marine deposits, Northwestern Alaska," in Annual Convention and Exposition of the American Association of Petroleum Geologists (San Francisco, CA), CONF-900605.

Keller, W. (2007). Implications of climate warming for Boreal shield lakes: a review and synthesis. Environ. Rev. 15, 99-112. doi: 10.1139/A07-002

Körner, C., and Paulsen, J. (2004). A world-wide study of high altitude treeline temperatures. J. Biogeogr. 31, 713-732. doi: 10.1111/j.1365-2699.2003.01043.x

Kowalski, E. A., and Dilcher, D. L. (2003). Warmer paleotemperatures for terrestrial ecosystems. Proc. Natl. Acad. Sci. U.S.A. 100, 167-170. doi: 10.1073/pnas.232693599

Kuc, M. (1974). Fossil flora of the beaufort formation, Meighen Island, Northwest territories. Geol. Sur. Can. 74-1A, 193-195. doi: 10.4095/103243

Li, S.-F., Jacques, F. M. B., Spicer, R. A., Su, T., Spicer, T. E. V., Yang, J., et al. (2016). Artificial neural networks reveal a high-resolution climatic signal in leaf physiognomy. Palaeogeogr. Palaeoclimatol. Palaeoecol. 442, 1-11. doi: $10.1016 /$ j.palaeo.2015.11.005

Marincovich, L. (2000). Central American paleogeography controlled Pliocene Arctic Ocean molluscan migrations. Geology 28, 551-554. doi: 10.1130/0091-7613(2000)28<551:CAPCPA>2.0.CO;2

Marincovich, L., and Gladenkov, A. Y. (2001). New evidence for the age of Bering Strait. Quat. Sci. Rev. 20, 329-335. doi: 10.1016/S0277-3791(00)00113-X

Matthews, J. V. Jr. (1987). Plant Macrofossils from the Neogene Beaufort Formation on Banks and Meighen Islands, District of Franklin. Geological Survey of Canada, Paper 87-1A, 73-87.

Matthews, J. V., Jr., and Fyles, J. G. (2000). "Late tertiary plant and arthropod fossils from the high-terrace sediments on Fosheim Peninsula, Ellesmere Island, Nunavut," in Environmental Response to Climate Change in the Canadian High
Arctic, Vol. 259, eds M. Garneau and B. T. Alt (Geological Survey of Canada), 295-317. doi: 10.4095/211969

Matthews, J. V., Westgate, J., Ovenden, L., Carter, L. D., and Fouch, T. (2003). Stratigraphy, fossils, and age of sediments at the upper pit of the lost chicken gold mine: new information on the late Pliocene environment of east central Alaska. Quat. Res. 60, 9-18. doi: 10.1016/S0033-5894(03)00087-5

Matthews, J. V. Jr., and Ovenden, L. E. (1990). Late tertiary plant macrofossils from localities in Arctic/Subarctic North America: a review of the data. Arctic 43, 364-392.

McBean, G., Alekseev, G., Deliang Chen, E. F., Fyfe, J., Groisman, P. Y., King, R., et al. (2005). "Arctic climate: past and present," in Arctic Climate Impact Assessment, eds C. Symon, L. Arris, and B. Heal (New York, NY: Cambridge University Press), 1020.

McNeil, D. H. (1990). Tertiary marine events of the beaufort-mackenzie basin and correlation of oligocene to Pliocene marine outcrops in Arctic North America. Arctic 43, 301-313. doi: 10.14430/arctic1626

Melles, M., Brigham-Grette, J., Minyuk, P. S., Nowaczyk, N. R., Wennrich, V., DeConto, R. M., et al. (2012). 2.8 million years of Arctic climate change from Lake El'gygytgyn, NE Russia. Science 337, 315-320. doi: $10.1126 /$ science. 1222135

Milla, R., and Reich, P. B. (2011). Multi-trait interactions, not phylogeny, finetune leaf size reduction with increasing altitude. Ann. Bot. 107, 455-465. doi: 10.1093/aob/mcq261

Miller, G. H., Alley, R. B., Brigham-Grette, J., Fitzpatrick, J. J., Polyak, L., Serreze, M. C., et al. (2010). Arctic amplification: can the past constrain the future? Quat. Sci. Rev. 29, 1779-1790. doi: 10.1016/j.quascirev.2010. 02.008

Mitchell, W. T., Rybczynski, N., Schröder-Adams, C., Hamilton, P. B., Smith, R., and Douglas, M. (2016). Stratigraphic and Paleoenvironmental reconstruction of a Mid-Pliocene fossil site in the high Arctic (Ellesmere Island, Nunavut): evidence of an ancient Peatland with beaver activity. Arctic 69, 185-204. doi: 10.14430/arctic4567

Moles, A. T., Perkins, S. E., Laffan, S. W., Flores-Moreno, H., Awasthy, M., Tindall, M. L., et al. (2014). Which is a better predictor of plant traits: temperature or precipitation? J. Veg. Sci. 25, 1167-1180. doi: 10.1111/jvs. 12190

Mosbrugger, V., and Utescher, T. (1997). The coexistence approach - a method for quantitative reconstructions of Tertiary terrestrial palaeoclimate data using plant fossils. Palaeogeogr. Palaeoclimatol. Palaeoecol. 134, 61-86. doi: 10.1016/S0031-0182(96)00154-X

Murphy, J. (2006). "Woody debris lenses: paleoenvironmental archives,"in Abstract Retrieved from Keck Symposium (Amherst, MA), 9, 20-25.

Murphy, J., Williams, C., and Sunderlin, D. (2007). "Woody debris lenses as paleoenvironmental archives" in Abstract Retrieved from Geological Society of America Abstracts with Programs (Denver, CO), 632.

Oksanen, J., Blanchet, F. G., Kindt, R., Legendre, P., Minchin, P. R., O'Hara, R., et al. (2015). Vegan: Community Ecology Package. R package version 2. 4-1 ed. Available online at: https://CRAN.R-project.org/package=vegan

Pagani, M., Liu, Z., LaRiviere, J., and Ravelo, A. C. (2010). High earth-system climate sensitivity determined from Pliocene carbon dioxide concentrations. Nat. Geosci. 3, 27-30. doi: 10.1038/ngeo724

Paulsen, J., and Körner, C. (2014). A climate-based model to predict potential treeline position around the globe. Alp. Bot. 124, 1-12. doi: 10.1007/s00035-014-0124-0

Ramírez, D. A., Foster, D. A., Min, K., Montes, C., Cardona, A., and Sadove, G. (2016). Exhumation of the Panama basement complex and basins: implications for the closure of the central American seaway. Geochem. Geophys. Geosyst. 17, 1758-1777. doi: 10.1002/2016GC006289

Raup, D. M., and Crick, R. E. (1979). Measurement of faunal similarity in paleontology. J. Paleontol. 53, 1213-1227.

R Core Team (2013). R: A Language and Environment for Statistical Computing. Vienna: R Foundation for Statistical Computing.

Revelle, W. (2016). psych: Procedures for Personality and Psychological Research, Version $=1$.6.9. Evanston, IL: Northwestern University. Available online at: https://CRAN.R-project.org/package=psych

Rybczynski, N., Gosse, J. C., Harington, C. R., Wogelius, R. A., Hidy, A. J., and Buckley, M. (2013). Mid-Pliocene warm-period deposits in the 
High Arctic yield insight into camel evolution. Nat. Commun. 4, 1-9. doi: $10.1038 /$ ncomms 2516

Salzmann, U., Dolan, A. M., Haywood, A. M., Chan, W.-L., Voss, J., Hill, D. J., et al. (2013). Challenges in quantifying Pliocene terrestrial warming revealed by data-model discord. Nat. Clim. Change 3, 969-974. doi: 10.1038/ nclimate 2008

Salzmann, U., Haywood, A. M., Lunt, D. J., Valdes, P. J., and Hill, D. J. (2008). A new global biome reconstruction and data-model comparison for the middle Pliocene. Glob. Ecol. Biogeogr. 17, 432-447. doi: $10.1111 / j .1466-8238.2008 .00381 . x$

Scherrer, D., and Körner, C. (2011). Topographically controlled thermal-habitat differentiation buffers alpine plant diversity against climate warming. J. Biogeogr. 38, 406-416. doi: 10.1111/j.1365-2699.2010.02407.x

Scott, P. A., Lavoie, C., MacDonald, G. M., Sveinbjörnsson, B., and Wein, R. W. (1997). "Change and future position of arctic tree line," in Global Change and Arctic Terrestrial Ecosystems, eds W. C. Oechel, T. Callaghan, T. Gilmanov, J. I. Holten, B. Maxwell, U. Molau, B. Sveinbjörnsson (New York, NY: Springer), 245-265.

Snucins, E., and Gunn, J. (2000). Interannual variation in the thermal structure of clear and colored lakes. Limnol. Oceanogr. 45, 1639-1646. doi: 10.4319/lo.2000.45.7.1639

Spicer, R. A., Bera, S., De Bera, S., Spicer, T. E. V., Srivastava, G., Mehrotra, R., et al. (2011). Why do foliar physiognomic climate estimates sometimes differ from those observed? Insights from taphonomic information loss and a CLAMP case study from the Ganges delta. Palaeogeogr. Palaeoclimatol. Palaeoecol. 302, 381-395. doi: 10.1016/j.palaeo.2011.01.024

Stap, L. B., de Boer, B., Ziegler, M., Bintanja, R., Lourens, L. J., and van de Wal, R. S. (2016). CO $^{2}$ over the past 5 million years: continuous simulation and new $\delta 11 \mathrm{~B}-$ based proxy data. Earth Planet. Sci. Lett. 439, 1-10. doi: $10.1016 /$ j.epsl.2016.01.022
Sugimoto, A., Yanagisawa, N., Naito, D., Fujita, N., and Maximov, T. C. (2002) Importance of permafrost as a source of water for plants in east Siberian taiga. Ecol. Res. 17, 493-503. doi: 10.1046/j.1440-1703.2002.00506.x

Tedford, R. H., and Harington, C. R. (2003). An Arctic mammal fauna from the early Pliocene of North America. Nature 425, 388-390. doi: $10.1038 /$ nature 01892

Therneau, T., Atkinson, B. and Ripley, B. (2015). rpart: Recursive Partitioning and Regression Trees. $\mathrm{R}$ package version 4.1-10. Available online at: https://CRAN.R-project.org/package=rpart

Verhoeven, K., Louwye, S., Eiríksson, J., and De Schepper, S. (2011). A new age model for the Pliocene-Pleistocene Tjörnes section on Iceland: its implication for the timing of North Atlantic-Pacific palaeoceanographic pathways. Palaeogeogr. Palaeoclimatol. Palaeoecol. 309, 33-52. doi: 10.1016/j.palaeo.2011. 04.001

Conflict of Interest Statement: The authors declare that the research was conducted in the absence of any commercial or financial relationships that could be construed as a potential conflict of interest.

The reviewer SF and handling Editor declared their shared affiliation, and the handling Editor states that the process nevertheless met the standards of a fair and objective review.

Copyright (c) 2017 Fletcher, Feng, Telka, Matthews and Ballantyne. This is an openaccess article distributed under the terms of the Creative Commons Attribution License (CC BY). The use, distribution or reproduction in other forums is permitted, provided the original author(s) or licensor are credited and that the original publication in this journal is cited, in accordance with accepted academic practice. No use, distribution or reproduction is permitted which does not comply with these terms. 